\title{
Intercultural pragmatics in the Global Englishes context: Some implications for developing intercultural communicative competence
}

\author{
MAGDALENA SZTENCEL
}

Received 27.04.2020, received in revised form 18.09.2020,

accepted 11.10.2020.

\begin{abstract}
The prevalent use of English as a lingua franca raises questions about the consequences for the practice of English Language Teaching. This paper investigates some of the pedagogical implications from the perspective of intercultural pragmatics. I argue that developing politeness strategies is an important aspect of enhancing learners' intercultural communicative competence. This is illustrated with the examples of speech acts such as requests, conditional threats and conditional promises. I draw attention to some fundamental misconceptions that may arise from an inadequate interpretation of cross-cultural findings, and argue that in order to establish which politeness strategies to use in the context of global communication, the focus of intercultural investigations needs to be shifted from studying lingua-cultural differences to studying lingua-cultural similarities.
\end{abstract}

\section{Keywords}

intercultural pragmatics, Global Englishes, intercultural communicative competence, English as a lingua franca, English Language Teaching 


\title{
Pragmatyka międzykulturowa w kontekście globalnego języka angielskiego: implikacje dla rozwoju międzykulturowej kompetencji komunikacyjnej
}

\begin{abstract}
Abstrakt
Powszechne używanie języka angielskiego jako lingua franca rodzi pytania o konsekwencje dla praktyki nauczania języka angielskiego. Poniższy artykuł bada niektóre implikacje pedagogiczne $z$ perspektywy pragmatyki międzykulturowej. Stawiam tezę, że rozwijanie strategii grzecznościowych jest ważnym aspektem wzmacniania międzykulturowych kompetencji komunikacyjnych uczniów. Powyższa teza jest zilustrowana przykładami aktów mowy, takich jak prośby, groźby warunkowe i obietnice warunkowe. Zwracam uwage na pewne fundamentalne nieporozumienia, które moga wynikać $z$ niewłaściwej interpretacji wyników badań międzykulturowych, i twierdzę, że aby ustalić, jakie strategie grzecznościowe zastosować w kontekście globalnej komunikacji, należy przesunać punkt ciężkości dociekań międzykulturowych ze studiowania różnic językowo-kulturowych na badanie podobieństw językowo-kulturowych.
\end{abstract}

\section{Keywords}

pragmatyka międzykulturowa, globalne angielskie, międzykulturowa kompetencja komunikacyjna, angielski jako lingua franca, nauczanie języka angielskiego

\section{Introduction}

Today, English is most commonly used as a lingua franca (Galloway and Numajiri 2019). This use involves communication between users from diverse linguistic and cultural backgrounds in a variety of contexts, ranging from personal to educational, business and political. The prevalent use of English in global contexts raises questions about the consequences for English Language Teaching. 
This paper investigates some of the implications that today's common use of English as a lingua franca has on pedagogical practice. The perspective taken is that of intercultural pragmatics, with a focus on speech acts such as requests, conditional threats and conditional promises.

The first part of this paper gives an overview of the Global Englishes framework and introduces the notion of intercultural communicative competence, which is crucially important when preparing learners for global communication. Then, three approaches to the study of intercultural pragmatics - cross-cultural communication, intercultural communication in interaction, and interdiscourse communication - are examined and an argument is made for the third of these approaches being the one best suited to the study of global communication.

The next sections look at the role of intercultural pragmatics and, more specifically, speech acts in an English language classroom. The concept of common ground is fundamental to the aspect of the intercultural communicative competence which I refer to as politeness strategies. This is followed by a discussion of whether cross-cultural comparisons can form the basis of recommendations for developing the intercultural communicative competence in learners. Some fundamental misconceptions that an inadequate interpretation of cross-cultural findings may yield are also addressed. Finally, I argue that in order to solve the pedagogical problem of which politeness strategies to use in the context of global communication, the focus of intercultural investigations needs to be shifted from studying lingua-cultural differences to studying lingua-cultural similarities.

\section{Global Englishes}

English as a Lingua Franca (ELF) refers to "any use of English among speakers of different first languages for whom English is the communicative medium of choice, and often the only option" (Seidlhofer 2011: 7). It involves communication between users from diverse linguistic and cultural backgrounds (Galloway and 
Numajiri 2019) who need to understand a range of lingua-cultural norms and codes in order to achieve communicative success (Canagarajah 2005). Lingua franca communication transcends the standardised English codes which are introduced in a traditional TESOL classroom (Galloway and Numajiri 2019) and assessed by standardised language testing (Hall et al. 2013). Indeed, the multifaceted nature of contexts and functions of English in the globalised world has led to the development of the Global Englishes framework (Galloway 2013, Galloway and Rose 2015), which incorporates research in the field of World Englishes (focusing on national varieties of English, such as British English or Sri Lankan English), English as a Lingua Franca (examining the use of English as a world language within and beyond the nation-based varieties) and hybrid-language practices such as translanguaging and plurilingualism (Galloway 2013, Galloway and Numajiri 2019, Galloway and Rose 2015).

Among the consequences of reconceptualising English within the Global Englishes perspective is a growing interest in the pedagogical implications. In particular, six areas for change have been identified as those that are essential in making English language teaching (ELT) more reflective of how English is used today. Following Galloway and Numajiri (2019), these Global Englishes Language Teaching (GELT) proposals include:

- increasing World Englishes and ELF exposure in language curricula;

- emphasising respect for multilingualism in ELT;

- raising awareness of Global Englishes in ELT;

- raising awareness of ELF strategies in language curricula;

- emphasising respect for diverse culture and identity in ELT;

- changing English teacher hiring practices in the ELT industry.

One of the overarching goals of GELT-oriented curriculum innovation is to prepare users of English for communication in multilingual and multicultural contexts or, in other words, "to foster 
intercultural communicative competence" (Galloway and Numajiri 2019: 5).

It is crucial to note that such intercultural communicative competence is intrinsically tied to the nature of ELF. As pointed out by Sung (2013: 177), ELF is not a variety of English; rather, it should be seen as a communicative activity. This activity is characterised by a variety of lingua-cultural contexts of use and a dynamic community of users "with different constellations of speakers of diverse first-language backgrounds in every interaction" (ibid.). In relation to English language teaching, Sung agrees with Hewings (2004) and Prodromou (2009), who argue that codified and standardised language models traditionally taught in TESOL classrooms should be thought of not as targets of learning but rather as reference points used to help learners develop their own variety of English and prepare themselves for communication in international contexts. As such, ELF is not in competition with the teaching of standardised varieties and forms of English, but is a functional extension of such teaching - an extension that enables learners to engage with English as it is used in real life.

In line with this argument, it is beneficial to expose learners to what Hall et al. (2015: 36-39) refer to as 'unstandardized' varieties of English, including the use of English by "native" as well as "non-native" speakers. Some examples of such exposure include:

- discovering the differences in spelling, pronunciation, use and meaning of slang words in the UK, USA, Australia and India (Lopriore 2016);

- raising students' awareness of accent variation (Sharifian and Marlina 2012);

- raising students' awareness of grammatical variation (McKay 2012);

- setting mini World Englishes research assignments for students to find information about the differences in pronunciation, grammar, vocabulary, idioms and communication styles 
pertaining to different varieties of English (Matsuda and Duran 2012);

- conducting activities that focus on raising awareness of how different social and cultural contexts affect the nature of language and meaning (Bayyurt and Altinmakas 2012);

- enhancing cross-cultural awareness with the aim of developing students' confidence about using their own variety of English (Lee 2012);

- using international news media to illustrate the diversity of cultural values and stances that users of ELF come across (Hino 2012).

Notably, the examples above illustrate the wide range of linguistic and cultural phenomena that users of ELF encounter and need to negotiate in order to develop their confidence and achieve communicative success in real-life situations. The next section explores a concept crucial to successful ELF communication, namely that of intercultural communication. Guidance will be provided on how to implement the GELT recommendation to raise awareness of ELF strategies in language curricula. More specifically, the section will lay a foundation for implementing Bayyurt and Altinmakas' (2012) point of raising awareness of how different social and cultural contexts can affect the nature of language and meaning in ELF situations.

\section{Intercultural communication}

Scollon and Scollon (2001) distinguish three types of approaches to intercultural communication:

- cross-cultural communication,

- intercultural communication, and

- interdiscourse communication.

The cross-cultural approach presupposes the existence of distinct, often nation-based, cultural groups (British, American) and involves comparative studies of patterns in the communicative practices of such groups. The intercultural approach is 
similar, in that it tends to begin with the assumption of cultural differences between distinct cultural or other (e.g. ethnic) groups, but it focuses on how members of such groups negotiate their differences in interaction. For the purposes of this paper, I will use the term 'intercultural communication in interaction' in this context; I will reserve the term intercultural communication' to refer to the field in general.

The third position listed above, namely the interdiscourse approach, assumes that in any communicative situation the participants are 'multiply positioned' within a complex system of identities (e.g. gender, age, ethnicity, profession, institutional, regional). These identities involve different ideologies and face relationships, and they may also be contradictory. Thus, the focus of the interdiscourse approach is the study of the dynamic, situated construction of cultural and other identities in discourse. In Scollon and Scollon's words (2001: 544), the aim of the interdiscourse approach is to ask "how and under what circumstances concepts such as culture are produced by participants as relevant categories for interpersonal ideological negotiation" (Scollon and Scollon 2001: 544).

As pointed out by Piller (2011), the different conceptualisations of intercultural communication listed above are not merely theoretical. They have real-life implications and may lead to social injustices, including unequal participation in education or the glass ceiling phenomenon which results from lingua-cultural stereotyping. Following Nakane (2007), Piller discusses the case of Japanese students in Australia whose silence in class was interpreted as part of their Japanese cultural identity. When interviewed, it transpired that most of the students wanted to participate actively but were uncomfortable about speaking up in class because they lacked confidence in their English, didn't know when they could speak or weren't sure about what was expected in class. Note that whereas the classification of silence as a cultural trait invites a passive acceptance of such behaviour on the part of the teacher, the 
understanding of its real causes is likely to prompt the teacher to find a solution.

Similarly, the reproduction of cross-cultural stereotypes may put individuals working in international companies at a disadvantage. In this context, a study of Finnish-Swedish post-merger companies carried out by Vaara (2000, cited in Piller 2011) found that:

[...] organizational actors often find cultural differences convenient attribution targets. Consequently, failures or unsuccessful experiences are often purposefully attributed to cultural differences, while successes are explained by other factors, such as the management's actions. (Vaara 2000: 105)

What these two cases illustrate is that there is an association between cultural stereotyping and "explanations" of failure. Indeed, Vaara (2000: 105) goes on to posit the existence of a cognitive tendency to explain problems which arise in intercultural contexts by appealing to cultural differences.

In the field of ELT, the cross-cultural approach appears to be predominant. As discussed by Alptekin (2002), integrating language and culture has long been assumed to be pedagogically valuable. However, the problem is that ELT materials tend to present an 'an idealized image of the English-speaking culture' (Alptekin 2002: 60). As a result, learners are instructed to use and interpret language in reference to monolithic, often nation-based, assumptions about cultural norms, rather than in relation to specific communicative situations. Alptekin goes on to argue that, to match the reality of ELF communication, ELT materials should highlight both inter- and intra-cultural diversity.

Looking at the issue from the teacher training perspective, Dogancay-Aktuna (2005: 100) elaborates on Scollon and Scollon's (1995) framework, arguing that pedagogical decisions on incorporating intercultural awareness in an ELT classroom need to be grounded in developing the teachers' awareness of the learners' socio-cultural assumptions. This includes an 
awareness of learners' common beliefs and dominant worldviews (Do they hold stereotypes?), socialization experiences (What do they assume should be taught in a language class?), attitudes toward languages and communicative practices (Are they aware of sociolinguistic relativity?) as well as politeness norms (What kinds of topics do they consider face-threatening?). The author cautions against reproducing the monolithic view of the target lingua-culture through generalising and constructing simplistic dichotomies while discussing such issues. Preparing teachers for intercultural ELT - hence, preparing learners for intercultural communication - should involve demonstrating areas in which discourse systems may vary as well as raising awareness of individual variation and the dynamic nature of communication.

Similarly, Baker (2011) rejects the monolithic, nation-based, perspectives on language and culture and argues that the concept of intercultural competence needs to involve 'expanded competencies' that will allow learners to navigate the dynamics of real-life ELF exchanges. Crucial to the notion of expanded competencies is the emergent and dynamic view of language and culture, which involves an awareness of the relative nature of cultural norms and an understanding of how language and culture are negotiated in particular communicative situations. In short then, expanded competencies require moving beyond the stereotypes implicated in generalisations of the 'our culture' / 'their culture' type.

Given that ELF is not a variety of English, but a communicative activity characterised by dynamic lingua-cultural contexts and users (Sung 2013), the approach of interdiscourse communication, with its focus on the situated and dynamic nature of communication is suitable for ELF instruction. Considering this, as well as the aforementioned problems that linguacultural stereotyping may lead to, the teacher and learner preparation for intercultural ELF communication, should involve:

- raising awareness of the problems that lingua-cultural stereotyping may lead to in educational and professional settings; 
- drawing attention to individual variation and the need to navigate the complex system of identities implicated in any conversational situation;

- discussing the above in relation to the monolithic lingua-cultural assumptions encountered in subject literature and teaching materials.

In the next section, intercultural communication is considered from the narrower perspective of intercultural pragmatics. In doing so, the grounds are laid for introducing another recommendation to the list above, namely:

- raising awareness of similarities in the politeness strategies implemented by users from diverse lingua-cultural backgrounds.

\section{Intercultural pragmatics}

Pragmatics is concerned with the use of language. It studies the ways in which meaning is communicated and interpreted by particular interlocutors in particular communicative contexts. The central topics of pragmatic inquiry include speech acts, conversational implicature, politeness, reference and deixis (e.g. Huang 2007, Levinson 2000).

How meaning is communicated and how utterances are interpreted depends, among other things, on the interlocutors' assumptions about their common ground, specifically the knowledge and beliefs that interlocutors in a conversation consider as shared for the purposes of communication (Clark 1994). As noted by Clark (1994: 989), successful communication depends on participants coordinating their actions through making assumptions about each other. Clark (1994: 989) distinguishes two types of common ground: communal common ground, which refers to the assumptions taken to be shared by members of the same community, and personal common ground, which concerns more specific mutual knowledge that interlocutors have learnt about each other from their previous experiences. In Clark's (1994: 990) words, common ground is 
"the back-ground, the context, for everything the participants jointly do and say in [discourse]".

The concept of common ground is fundamental to understanding one aspect of intercultural communicative competence, namely social and pragmatic competence. Social and pragmatic competence involves an awareness of conversational conventions which, in turn, depend on the appreciation of how various relations between people and situational contexts affect the linguistic forms used in communication (e.g. Spiro 2013: 191). For example, a conversation between a boss and an employee may be more or less formal depending on the relationship between these two people. This in itself may depend upon their assumptions about each other's personalities, their knowledge of institutional codes which apply in a particular setting, as well as an understanding of the extent to which a particular interlocutor tends to abide by such codes. A parent-child discussion may be informal at a dinner table, assuming a partner-like relationship between them, but more formal in a school office in the presence of a teacher who is known to keep a degree of social distance in parent-teacher meetings. But what about talking to people whose background and conversational preferences are unknown to us? According to Friedrich (2021: 48), in such 'unfamiliar' contexts we draw on communicative strategies that help us make up for the missing information.

Friedrich (2021: 48) goes on to argue that such 'unfamiliarity' - which we can now conceptualise in terms of missing common ground assumptions - encountered when interacting with people we do not know, or do not know much about, is common in ELF situations, where linguistic diversity adds another dimension. Consequently, ELT classroom work should help students develop competence in choosing adequate and respectful communicative strategies.

What communicative strategies should be taught? According to Vettorel (2018), cooperative negotiation and the co-construction of meaning characteristic of ELF encounters involves a range of strategies for solving non-understandings or pre- 
empting potential non-understandings, all of which should receive more attention in ELT classrooms and materials. This includes interactional strategies, such as appeals for help or comprehension checks; achievement/compensatory strategies, such as circumlocution, word-coinage and code-switching; stalling/time-gaining strategies, such as fillers; and self-monitoring strategies, such as self-initiated repair (c.f. Celce-Murcia et al. 1995) . In the next section, I argue that the list should be expanded to include politeness strategies. I elaborate on this proposal by focusing on speech acts.

\section{Speech acts}

Let me begin this section by describing a situation I encountered many years ago when I was an ELT practitioner teaching incompany English courses at a British company based in Poland. A British representative of the company, who was paying an official visit to the Polish site, commented on my students' English in the following way: Your students' English is really good and I know they are nice people, but they come across as brusque. They should say 'please' more often. Later, when I talked to my students about this comment, they were surprised: Whenever I make requests in English, I say 'Could you ...' instead of 'Can you ...'. Isn't that polite enough?.

Bardovi-Harlig and Mahan-Taylor (2003) have situations like this in mind when they point out that foreign language learners tend to use and understand certain speech acts differently from the native speakers of the target language. Such differences may be interpreted at a personal rather than linguistic level; for example, the learner's use of language may be interpreted as brusque or rude, potentially leading to denial of requests (Mahan-Taylor 2003). Considerations like these point to the importance of pragmatic instruction in ELT, the aim of which is to raise the learners' awareness about pragmatics and enable them to have control of their linguistic contributions (Bardovi-Harlig and Mahan-Taylor 2003). The authors stress 
that such instruction should aim to familiarise learners with the range of available pragmatic devices and practices.

The situation I described above seems to agree with the extant research which suggests that the socio-pragmatics of, for example, Spanish, Greek, Polish, Russian and Hebrew is characterised by a greater employment of direct strategies for performing speech acts when compared to English (e.g. BlumKulka 1989, Sifianou 1992, Ogiermann 2009). Indeed, Chałupnik's (2011) study of request strategies found that Polish respondents chose a direct request strategy $34 \%$ of the time, compared with $22 \%$ in the case of English speakers. Direct criticism was chosen $48 \%$ of the time by Poles, compared with $32 \%$ in the case of English speakers. Let us consider these findings in relation to the anecdote that I started this section with. However, before I begin, a caveat is in order: in what follows I do not criticise the studies cited in this and the next section, but draw attention to a potential superficial interpretation of the generic findings of these studies.

Firstly, recall that Could you ...? without please was not indirect enough according to the lingua-cultural conventions my visitor was operating within. This could be explained in relation to Chałupnik's generic findings: the lower preference for direct requests by English speakers than Polish speakers could explain the British visitor's perception of my students as brusque. However, the fact that my students wanted to be (and thought they were) polite enough, as we recall their comment on choosing Could you ...? instead of Can you ...? , could also be explained by Chałupnik's data. In this case, the relevant finding is the tendency of Polish speakers to avoid direct strategies for making requests - after all, $66 \%$ of the time direct requests were not chosen by the Polish respondents. Furthermore, the fact that direct requests were not rejected outright by the English respondents (direct requests were chosen $22 \%$ of the time) could explain the fact that my visitor did not hedge his recommendation that my students should say 'please' more often. Another problem is that, by definition, a cross-cultural (i.e. nation- 
based) approach will not focus on the question of whether my visitor's directness may have been a matter of power relations the visitor might have felt entitled to be direct when talking to me because he was in a senior position to both my students and myself. Neither will the cross-cultural approach look at the question of whether personal relations between the interlocutors could have been at play here - the visitor might have felt entitled to be direct when talking to me because he was a good friend of mine.

What I hope to have shown with this example is this: when we focus on the differences between the purported nation-based cultures, cross-cultural approaches to lingua-cultural politeness will inevitably yield results which over-generalise and are thus nonexplanatory. What they show is that there may be some nation-based tendencies, but they are too generic to focus on individual variation. In other words, they are not fine-grained enough to be used as a basis for making recommendations on how to interact when talking to the English, the Polish, the Germans, etc.

Considerations like these illustrate the limitations in the explanatory power of cross-cultural generalisations. This in turn gives further credibility to the calls to embed the interdiscourse approach in ELF communication studies. Such an approach is in line with Widdowson's (1998) more general observation that for language to be pragmatically authentic, it needs to be situated, or localised, in a specific discourse community. This is true of any communicative context, including the pragmatic choices that speakers make in ELF situations.

However is there anything about cross-cultural findings that could serve as a basis for ELF practice recommendations? In fact, cross-cultural findings could be directly applied to solving the problem of what politeness strategies to use in the context of missing common ground assumptions (Friedrich's 'unfamiliar' contexts). However, this will only be possible when the focus is shifted from the differences revealed in cross-cultural studies to the similarities uncovered by such studies. In this 
context, note that what Chałupnik's study of English and Polish request preferences demonstrates is that, despite a higher tolerance for direct requests among the Polish respondents, there is a tendency to avoid direct requests by speakers of both languages. The implication of this is as follows: even though direct requests in English (and Polish) are acceptable in some situations for some users (e.g. between friends), in unfamiliar contexts, including ELF contexts, it is advisable to use indirect requests because direct requests may come across as brusque. This should be accompanied by an overview of structures used to make direct and indirect requests in English and their comparison to the structures used in the students' first language.

In the next section, I look more specifically at the intercultural pragmatic aspects of conditional inducements. This will help to illustrate another problem with interpreting cross-cultural findings.

\section{Conditional inducements and intercultural pragmatics}

Conditional inducements are statements made to influence the hearers' behaviour by telling them about the consequences of their behaviour (Searle 1971). They can take the form of a conditional promise, as in (1) below, or a conditional threat, as in (2).

(1) If you work hard, I'll take you to a restaurant.

(2) If you don't eat your dinner, I won't give you the pudding.

The conditional promise (1) is used to influence the hearer's behaviour by promising that a reward will be given (the hearer will be taken to a restaurant by the speaker) if the hearer performs the action desired by the speaker (the hearer works hard). The conditional threat (2) is used to influence the hearer's behaviour by threatening that a punishment will ensue (the hearer will not get the pudding) if the hearer behaves in a way which is undesired by the speaker (the hearer doesn't eat the dinner). 
Note that speakers have a choice of formulating the inducement in (1) as a threat (If you don't work hard, I won't take you to a restaurant) and the inducement in (2) as a promise (If you eat your dinner, I will give you the pudding). The difference in the formulation of a conditional inducement is of a motivational type (e.g. Beller 2002, Beller et al. 2005, Fillenbaum 1986, Searle and Vanderveken 1985). Put simply, it is about framing the incentive as a reward or as a punishment. This motivational difference carries with it a wealth of assumptions about the speaker's deontic commitments, which are grounded in a network of complex social relations that the interlocutors assume of each other (part of their common ground). These assumptions concern the questions of what the speaker of a conditional inducement is or isn't permitted and obliged to do. For example, does the speaker have to inflict the stated punishment if the hearer of a conditional threat does not cooperate?

For the purposes of this paper, I will consider two experimental studies of conditional inducements. The first is Beller et al.'s (2005) study into conditional promises and threats in German. The second is Sztencel and Clarke's (2018) English language replication of Beller's original study. Both studies were cognitive and neither of them were cross-cultural in nature (but see Beller et al. 2004, 2009); however, the fact that we have two sets of data from two languages, which were collected with the same instrument, allows us to compare the two sets of findings. In both cases, the participants were university students. In Beller et al.'s (2005) study, there were 66 students, 34 of whom were male and 32 female, with the mean age of 22.7 years (age range 20-32). 70 students took part in Sztencel and Clarke's (2018) study, 34 of whom were male and 36 female, with a mean age 20.1 years (age range 18-32). In what follows, I focus on one of the tasks that the participants in both studies completed, namely the formulation task, which I explain below.

Let us look deeper into the question of how conditional inducements can be formulated. Following Beller et al. (2005), I will use the term canonical to refer to "if $p$, then q" formulations, 
in which the information about the hearer's behaviour temporally/linearly precedes the information about the (dis)incentive, as in (1) and (2) above. As already discussed, the conditional promise in (1) can be (re-)formulated as a threat and the conditional threat in (2) can be (re-)formulated as a promise. The resulting (re-)formulations - If you don't work hard, I won't take you to a restaurant and If you eat your dinner, I will give you the pudding - will be referred to as complementary formulations. Arguably, some conditional promises can also be formulated using a reversed form of "if $q$, then $p$ " (If I give you the pudding, you will eat the dinner). However, the reversed formulation is inappropriate for conditional threats (?If I don't take you to a restaurant, you won't work hard). Conversely, it seems that conditional threats can be formulated using the reversed-complementary form, resulting in If I take you to a restaurant, you will work hard, but promises cannot (?If I don't give you the pudding, you won't eat the dinner).

In the formulation task, the participants were provided with a mutual exchange scenario, like the one below, and informed about whether the speaker will use a promise or a threat.

Usually, Frank doesn't lend his bike to his schoolmates. However, Henry wants to borrow it today. Henry tries to reach this goal by threatening Frank with something. Henry knows that Frank would like his help with today's homework, and usually Henry helps him.

The participants were then presented with four conditionals (canonical, complementary, reversed and reversed-complementary) and instructed to select the one that seemed 'the best choice' for the speaker's intended inducement. The choices were:

(a) "Frank, if you lend me your bike, then I will help you with your homework."

- Canonical for promises, complementary for threats 
(b) "Frank, if you do not lend me your bike, then I will not help you with your homework."

- Canonical for threats, complementary for promises

(c) "Frank, if I help you with your homework, then you will lend me your bike."

- Reversed for promises, reversed-complementary for threats

(d) "Frank, if I do not help you with your homework, then you will not lend me your bike."

- Reversed-complementary for promises, reversed for threats

The participants were assigned into four experimental groups, which varied by the type of the inducement and the ordering of the choices. Table 1 summarises the findings from the formulation task in the German and English studies.

In the German study, the results revealed no significant statistical difference in the frequency of the canonical formulation of conditional promises and threats when compared with the total of the other three possibilities (Beller et al. 2005). However, this difference was significant in the English study $(p=.028)$. In short, the participants in the English study were keener to avoid the canonical threat formulation than the participants in the German study: a significant number of English participants formulated the threat as a promise (complementary) or a reversed promise (reversed-complementary). We could say that these participants chose to threaten indirectly.

At this point, one might be tempted to attribute this difference to cross-cultural variation, especially when one learns that Beller and Bender's (2004) study found a significant difference in the Tongan participants' formulation preferences. $64 \%$ of the Tongan participants chose the canonical promise formulation (reversed $=18 \%$, complementary $=12 \%$, reversed-complementary $=6 \%$ ) and only $41 \%$ of the Tongan participants chose the canonical threat formulation (complementary $=38 \%$, reversedcomplementary $=21 \%$ ). 
Table 1

Summary of the formulation task choices for German (Beller et al. 2005) and English (Sztencel and Clarke 2018)

\begin{tabular}{|l|c|c|}
\hline & German & English \\
\hline Promises \% & & \\
\hline Canonical & 94 & 86 \\
\hline Complementary & 6 & - \\
\hline Reversed & - & 11 \\
\hline Reversed-complementary & - & 3 \\
\hline Threats \% & & \\
\hline Canonical & 85 & 62 \\
\hline Complementary & 15 & 23 \\
\hline Reversed & - & - \\
\hline Reversed-complementary & - & 15 \\
\hline
\end{tabular}

Beller and Bender (2004: 89) suggest that because "cooperation and particularly sharing with others are core values in the Tongan society, threats may simply be not appropriate as a means of initiating an exchange" [my emphasis added].In cross-comparison, the English participants were more likely to choose the canonical threat formulation than the Tongans, but less likely to do so than the Germans. But can we be sure that this variation is due to the cross-cultural differences in social conventions?

Sztencel and Clarke (2018) voice a concern about attempts to interpret these differences in cross-cultural terms. First, unlike the participants in Beller et al.'s (2005) and Sztencel and Clarke's (2018) studies, Beller and Bender's (2004) Tongan participants were secondary school students with the mean age of 15.4. Thus, a feasible interpretation of the difference is that the older German and English students were more successful at disregarding their the socio-linguistic conventions for the purpose of engaging in the formulation task. It may be the case that the participants who chose the canonical threat formulation in any of the three studies would actually choose to formulate their inducements as promises in real life. Indeed, in Beller et al.'s 
(2009) German study, in which the participants were secondary school students with the mean age of 16.6 , only $16 \%$ chose the canonical threat formulation (59\% complementary, $22 \%$ reversed). In other words, the choice of the indirect strategy among the secondary-school German participants was higher than among the Tongan, the English and the German participants that took part in Beller et al.'s 2005 study. Again, these participants' choices may have been influenced by their real-life linguistic preferences in combination with an under-developed skill at putting aside their socio-linguistic conventions in order to follow the instructions of an experimental study.

Based on this overview, the recommendation for practice will be similar to the one that I made for requests. Even though conditional threats are used in English (and German and Tongan) in some situations by some users (presumably, an example would be parent-child communication), in unfamiliar contexts, including ELF contexts, it is advisable to formulate conditional inducements as conditional promises. This should be accompanied by a discussion of the differences between conditional threats, which are likely to be interpreted as impolite, and conditional warnings (e.g. If you don't work hard, they'll fire you; If you don't press this button now, the engine will explode), which are acceptable. This should be followed by a comparison with the relevant structures used in the students' first language.

Note that when politeness strategies are taken into account, it is no longer sufficient for ELT materials to highlight inter- as well as intra-cultural diversity in order to match the reality of ELF communication (c.f. Alptekin 2002). I hope to have demonstrated that the similarities in the use of pragmatic politeness strategies by speakers with different lingua-cultural backgrounds also need to be highlighted.

\section{Conclusion}

This paper set out to investigate some implications that the use of English as a lingua franca has on the practice of English 
Language Teaching. The question has been discussed in the context of the Global Englishes framework and linked to the interdiscourse approach to the study of intercultural pragmatics. I have argued that politeness strategies are an important aspect of developing learners' intercultural communicative competence. This competence stresses the significance of intercultural pragmatics instruction in an English language classroom.

I have drawn attention to the fact that an inadequate interpretation of cross-cultural data may give rise to fundamental misconceptions about intercultural communication. Finally, I have argued that the focus of intercultural communication studies needs to be shifted away from the investigation of differences and toward the investigation of similarities in communicative strategies and trends used by speakers from different lingua-cultural backgrounds. Such a shift will allow us to determine what politeness strategies should be employed in the context of using English for global communication.

\section{References}

Alptekin, Cem (2002). "Towards Intercultural Communicative Competence in ELT". ELT Journal 56/1: 57-64.

Baker, Will (2011). "Intercultural awareness: Modelling an understanding of cultures in intercultural communication through English as a lingua franca". Language and Intercultural Communication 11/3: 197-214.

Bardovi-Harlig, Kathleen, Rebecca Mahan-Taylor (2003). "Introduction to teaching pragmatics". English Teaching Forum 41/3: 3739.

Bayyurt, Yasemin, Derya Altinmakas (2012). "A WE-based English Communication Skills Course at a Turkish University". In: A. Matsuda (ed.). Principles and Practices of Teaching English As an International Language. Bristol: Multilingual Matters, 169-182.

Beller, Sieghard (2002). "Conditional promises and threats - cognition and emotion". In: Wayne D. Gray, Christian D. Schunn (eds.). Proceedings of the Twenty-Fourth Annual Conference of the Cognitive Science Society. Mahwah, NJ: Lawrence Erlbaum, 113-118. 
Beller, Sieghard, Andrea Bender (2004). "Cultural differences in the cognition and emotion of conditional promises and threats - comparing Germany and Tonga". In: Kenneth D. Forbus, Dedre Gentner, Terry Regier (eds.). Proceedings of the Twenty-Sixth Annual Conference of the Cognitive Science Society. Mahwah, NJ: Lawrence Erlbaum Associates Inc., 85-90.

Beller, Sieghard, Andrea Bender, Gregory Kuhnmünch (2005). "Understanding Conditional Promises and Threats". Thinking and Reasoning 11/3: 209-238.

Beller, Sieghard, Andrea Bender, Jie Song (2009). "Conditional Promises and Threats in Germany, China, and Tonga: Cognition and Emotion". Journal of Cognition and Culture 9: 115-139.

Blum-Kulka, Shosana (ed.) (1989). Cross-Cultural Pragmatics: Requests and Apologies. Norwood: Ablex Publishing Corporation.

Canagarajah, Suresh (2005). Reclaiming the Local in Language Policy and Practice. Mahwah, NJ: Lawrence Erlbaum.

Celce-Murcia Marianne, Zoltan Dörnyei, Sarah Thurrel (1995). "Communicative Competence: A Pedagogically Motivated Model with Content Specification". Issues in Applied Linguistics 6/2: 5-35.

Chałupnik, Małgorzata (2011). "Realisation of requests and criticisms in Polish and British English. Working With English: Medieval and Modern Language". Literature and Drama 7: 33-45.

Dogancay-Aktuna, Seran (2005). "Intercultural communication in English language teacher education". ELT Journal, 59/2: 99-107.

Eslami, Zohreh R. (2011). "In Their Own Voices: Reflections of Native and Nonnative English Speaking TESOL Graduate Students on On-Line Pragmatic Instruction to EFL Learners". TESL-EJ, 15/2: $1-21$.

Fillenbaum, Samuel (1986). "The use of conditional inducements and deterrents". In: Traugott, Elizabeth Closs, Alice ter Meulen, Judy Snitzer Reilly, Charles A. Ferguson (eds.). On Conditionals. Cambridge: Cambridge University Press, 179-195.

Friedrich, Patricia (2012). "ELF, intercultural communication and the strategic aspect of communicative competence". In: Aya Matsuda (ed.). Principles and practices of teaching English as an international language, vol. 25, Bristol: Multilingual Matters, 44-54.

Galloway, Nicola (2013). "Global Englishes and English language teaching (ELT): Bridging the gap between theory and practice in a Japanese context". System 41: 786-803. 
Galloway, Nicola, Takuya Numajiri (2019). "Global Englishes Language Teaching: Bottom-up Curriculum Implementation”. TESOL Quarterly, 1-28.

Galloway, Nicola, Heath Rose (2015). Introducing Global Englishes. Abingdon, England: Routledge.

Hall, Christopher J., Patrick H. Smith, Rachel Wicaksono (2015). Mapping Applied Linguistics: A Guide for Students and Practitioners. Abingdon-on-Thames, UK: Routledge.

Hall Christopher J., Rachel Wicaksono, Shu Liu, Yuan Qian, Xu Xiaoqing (2013). "English reconceived: Raising teachers' awareness of English as a 'plurilithic' resource through an online course. ELTRA Research Papers: 13-05. Available at http://teachingenglish.britishcouncil.org.cn/sites/teacheng/ files/D053 \%20Raising \%20teachers \%20awareness \%20of \%20English_ONLINE \%20FINAL.pdf

Hewings, Martin (2004). Pronunciation Practice Activities: A Resource Book for Teaching English Pronunciation. Cambridge: Cambridge University Press.

Hino, Nobuyuki (2012). "Participating in the Community of EIL Users Through Real-Time News: Integrated Practice in Teaching English as an International Language (IPTEIL)". In: Aya Matsuda (ed.). Principles and Practices of Teaching English As an International Language. Bristol: Multilingual Matters, 183-200.

Lee, Hyewon (2012). "World Englishes in a High School English Class: A Case from Japan". In: Aya Matsuda (ed.). Principles and Practices of Teaching English As an International Language. Bristol: Multilingual Matters, 154-168.

Lopriore, Lucilla (2016). "ELF in Teacher Education: A Way and Ways". In: Lucilla Lopriore, Enrico Grazzi (eds.), Intercultural communication: New perspectives from ELF Rome, Italy: Roma TrE-Press, $167-188$.

McKay, Sandra Lee (2012). "Teaching Materials for English as an International Language". In: Aya Matsuda (ed.). Principles and Practices of Teaching English As an International Language. Bristol: Multilingual Matters, 70-83.

Matsuda, Aya, Chatwara Suwannamai Duran (2012). "EIL Activities and Tasks for Traditional English Classrooms". In: Aya Matsuda (ed.). Principles and Practices of Teaching English As an International Language. Bristol: Multilingual Matters, 201-238. 
Nakane, Ikuko (2007). Silence in Intercultural Communication. Perceptions and Performance. Amsterdam: John Benjamins Publishing Company.

Ogiermann, Eva (2009). "Politeness and In-directness Across Cultures: A Comparison of English, German, Polish and Russian Requests". Journal of Politeness Research 5: 259- 286.

Prodromou, Luke (2009). "Review of English as a lingua franca: A corpus-based analysis". ELT Journal 63: 78-81.

Scollon, Ron, Suzanne Wong Scollon (1995). Intercultural Communication. Oxford: Basil Blackwell.

Scollon, Ron, Suzanne Wong Scollon (2001). "Discourse and Intercultural Communication". In: Deborah Schiffrin, Deborah Tannen, Heidi E. Hamilton (eds.). The Handbook of Discourse Analysis. Oxford: Blackwell, 538-547.

Searle, John R. (1971). "What is a speech act?". In: J. R. Searle (ed.). The Philosophy of Language. London: Oxford University Press, 3953.

Searle, John R., Daniel Vanderveken (1985). Foundations of Illocutionary Logic. Cambridge: Cambridge University Press.

Seidlhofer, Barbara (2011). Understanding English as a Lingua Franca. Oxford: Oxford University Press.

Sharifian, Farzad, Roby Marlina (2012). "English as an International Language (EIL): An innovative academic". In: Aya Matsuda (ed.). Principles and Practices of Teaching English As an International Language. Bristol: Multilingual Matters, 140-153.

Sifianou, Maria (1992). Politeness Phenomena in England and Greece: a Cross-Cultural Perspective. Oxford: Clarendon Press.

Spiro, Jane (2013). Changing Methodologies in TESOL. Edinburgh: Edinburgh University Press.

Sung, Chit Cheung Matthew (2013). "English as a lingua franca and its implications for English language teaching". JALT Journal 35/2: 177-194.

Sztencel, Magdalena, Leesa Clarke (2018). "Deontic commitments in conditional promises and threats: towards an exemplar semantics for conditionals". Language and Cognition 10/3: 435-466.

Vettorel, Paola (2018). "ELF and communication strategies: Are they taken into account in ELT materials?". RELC Journal 49/1: 58-73.

Widdowson, Henry G. (1998). "Context, community, and authentic language”. TESOL Quarterly 32/4: 705-16. 
Magdalena Sztencel

ORCID iD: 0000-0002-5444-0883

Instytut Anglistyki i Amerykanistyki

Uniwersytet Gdański

ul. Wita Stwosza 51

80-308 Gdańsk

Poland

magdalena.sztencel@ug.edu.pl 